\title{
Analysis on the Necessity of Protection and Inheritance of Intangible Culture Heritage of Music in Campus Conditions
}

\author{
Zhenhua Wang \\ Henan Institute of Education \\ Zhengzhou, China
}

\begin{abstract}
Music intangible culture is a major component of the non-material culture, which is from life and higher than life as an art form. It takes advantage of the tune ups and downs, dielectric relaxation and reasonable body movements to fully demonstrate the work content, form and emotion in front of the audience in order to shock their heart and soul. As an important venue of bearing the music development, how to inherit and protect the music intangible culture in the campus environment has become the must considering question in music education. Therefore, this article focus on the analysis and research on the general status of music intangible culture, the importance and measurement on inheritance and protection of music non-material culture in campus environment.
\end{abstract}

Keywords-campus environment; intangible culture heritage of music; inheritance; protection; general status; importance; measurement; traditional music; national culture

\section{INTRODUCTION}

As a nation with long history and culture, the Chinese nation shows her broad and profound historical culture in the 5000 years of history and gives birth to the rich and colorful national intangible culture, which is not only the premise condition for building the traditional culture of the Chinese nation, but also the foundation of diverse national culture in China. The core of the intangible cultural heritage protection work is the realization of live transmission. As the main component of non-material culture, music intangible culture inherits the national culture and spirit by its own richness, which is an importance show on cultural consciousness \& people's wisdom. Due to its characteristics of invisibility, regional, mass and historic, how to adapt to the ecological environment change on the sustainable development of music culture is very important to the non-material culture of music in the global economy development environment. As a basis to music education, colleges and universities should shoulder the responsibility of protecting and inheriting the music class intangible cultural heritage, and the ways of taking advantage of the campus resource, the campus culture construction and perfecting the curriculum system on the music class intangible cultural and so on to protect the music class non-material culture heritage.

\section{General Status of the Music Class INTANGIBLE CULTURE HERITAGE}

The Convention on the Protection of Intangible Cultural Heritage promulgated in 2003 by UNESCO has described the "intangible cultural heritage" is all kinds of social practice, expression of concept, form of expression, knowledge, technology, or other tools, physical, handicrafts and cultural sites which is taken a part of the cultural heritage by the community, groups or individual. In 2005, the State Council analyses the "intangible cultural heritage "in the General Office of the State Council on Strengthening the Opinions of the Intangible Cultural Heritage Protection Work in China, and refers that it should be the various manifestations of traditional culture and the cultural space succeeding by all ethnic groups and closely linking to people's life. As an important part of intangible cultural heritage, the non-material cultural heritage of music can be understood as the forms of the artistic expression showed by some communities, groups and individuals and satisfied the group and has the corresponding social value of melody, rhythm, harmony, and instrumental music. Traditional folk music, folk dance, drama and instrumental music art are the main content of our intangible cultural heritage of music. Asked the non-material cultural heritage can be generated among the masses, and be automatic passed down in the historical vicissitude. The inheritance and protection of nonmaterial cultural heritage of music mainly depends on three aspects:

First, take the government as the main body to give policy support. The government improves the intangible cultural heritage protection and inheritance emphasis, and protects the intangible cultural heritage through the relevant policy.

Second, rely on relevant research institutes to collect, sort and research the intangible cultural heritage.

Third, improve the enthusiasm of the group and the masses for protecting intangible cultural heritage.

The non-matter cultural heritage of music constitutes the main ingredients of traditional Chinese culture, it is very important among the people's oral and the protection of the intangible cultural heritage, which guarantees the inheritance 
of the people of all ethnic groups in the folk music. Along with the increasing strength of non-material cultural heritage protection, the non-matter cultural heritage of music has become a focus in academic circles, the cultural and social value is great, so the phenomenon of valuing declare but despising protection to it should be forbidden in the process of protection. As an important field for music culture dissemination, Collage not only provides the students with learning music sites, but also provides the opportunity for more in-depth knowledge, understanding and music innovation. In campus environment, how to achieve the purpose of inheritance and protection of the intangible culture of music is very important for music teaching. Therefore, the advantage of music culture in the music course in colleges and universities must be fully displayed, which has important meaning to make strategic deployment for speeding up the construction of strengthening the educational culture in universities, increase the pace to develop the music culture of school. Under the premise condition of fully understanding the importance of nonmaterial cultural heritage and protection of music, preservation and dissemination of heritage measures should be taken, which not only has important meaning on constructing the harmonious campus and the advanced culture, but also has a key role on improving the level of contemporary music creation and enriching the teaching content.

\section{THE IMPORTANCE OF THE PROTECTION AND INHERITANCE FOR THE NON-MATERIAL CULTURAL HERITAGE OF MUSIC IN CAMPUS CONDITIONS}

In 2004, the National Ministry of Education sports health and artistic education department issued the guidance plan for musical education (teacher education) in common colleges and universities, which strictly regulated the music teaching course in campus, such as determine the class hours and credits according to the regional and national music education regulation and school places and course arrangement. In general there are 180 class hours and 10 credits. The released document provides good conditions for the reform of music education and arrangement of music curriculum, and also provides good way for strengthening reform of music education curriculum. To give priority to courses in music intangible cultural heritage can help students further understand the music culture and to deepen the understanding of intangible cultural heritage. Taking music intangible cultural heritage into the teaching of music can fully display the campus advantage. Inspire culture and educate the student through the simplest form of music language and form, which can promote and musical culture accomplishment of the students and also can broaden their horizons and edify their sentiment.

At present, "People and arts share a common fate" has become the main phenomenon for the existence of nonmaterial cultural heritage of music, which is very fragile and uncertain. Thus, people's inheritance is very important. Set up the archives of the inheritance people by relying on colleges and universities, such as personal data and artistic performance data and so on, and take advantage of the record and video to collect and record its bearing cultural art. Especially the advent of the era of multimedia provides more preservation way for non-material cultural heritage of music, which is good for inheritance and protection of it. Under the influence of diversity archives carrier, students can more intuitively, concretely and comprehensively understand cultural verve and landscape.

It can turn resource advantage to the cultivation of talents advantage by the comprehensive advantages of provincial art college in music culture dissemination, such as history, culture, etc., and take the characteristics of the curriculum as a starting point to construct the education system of music intangible cultural heritage. At the same time, encourage teachers to write notes, actively carry out declaration activities for characteristic teaching materiel, and help the folk music art to declare the non-material cultural heritage list .Take the intangible cultural heritage into music education and musical class to create the inheritance and protection space for intangible cultural heritage by using the platform of campus environment. At the same time, fully display the collages advantages on training music talent. Take the local musical arts into the teaching content and hold all kinds of heritage activities such as developing folk instrumental music concert, setting up student associations and opening non-material cultural heritage, etc., to absorb nutrients in abundant precipitation of historical culture and to use it in the teaching to high light the local talent training features, so that to train the traditional music talent with high quality and high educational background. And then further improve the research level via original documents so that to create outstanding music works under the heritage precondition.

\section{THE MEASURES OF THE PROTECTION AND INHERITANCE FOR THE NON-MATERIAL CULTURAL HERITAGE OF MUSIC IN CAMPUS CONDITIONS}

The campus environment is very important for the protection and inheritance for the non-material cultural heritage of music. The institutions of higher learning should be responsible of the historical mission of protecting and inheriting the traditional music as a research institution with the culture protection consciousness. Institutions of higher learning can provides lots of excellent talents for the research of non-material culture and it has the related researching sites and equipment, and the teachers and students have a relatively strong sense of cultural preservation at the same time. The main measures include the following contents:

\section{A. Take Advantage of the Software and Hardware Resource}

In order to adapt to environmental changes of cultural pluralism and diversity, the colleges and universities should take the responsible for protecting the national culture, regional culture and world culture. The colleges and universities can do talent cultivation, social service and research on innovation level in the construction of national culture. The teachers in colleges and universities is relatively abundant after long-term development, which provides the spreading and broadening advantages for inheritance and protection of the non-material cultural heritage of music, 
especially to help students to establish correct values, world view by teachers' practice and to help students to raise awareness of protecting intangible cultural heritage of music can provide strong support for protection of it.

The national policy support avoids the funding problems at some extent which will bring difficulties for this work. In order to improve the protection level of the non-material culture of music, the research institutions of university must ensure the public welfare of the work nature in the research of intangible cultural heritage. At the same time, the cultural protection activities, the workers must have rich knowledge when the cultural protection activities are held, such as the ethnomusicology, world musicology, folk customs and other relevant knowledge. It is not possible to complete the scientific research work only by general information query conditions during the inheritance of the intangible cultural heritage of music, therefore, the workers can make full use of resources of the library and multimedia equipment and so on to clearly arrange and collect the related documents about the non-material cultural heritage of music, and use the advanced science and technology to record and save it.

\section{B. Strengthen the Construction of Campus Culture}

To edify sentiment, stimulate learning and adjust the atmosphere can help to build up the harmonious campus culture and strengthen the construction of campus culture, which not only can improve the mental outlook, but also can help the school set up good public image. In order to protect and inherit the intangible cultural heritage of music, the colleges and universities can fully connect the characteristics of local arts of the intangible cultural heritage, and carry out communication activities on a regular basis together with the art inheritance people, and hole a series of cultural heritage lecture to improve the consciousness of the students on nonmaterial cultural protection. At the same time, establish the related music community and strengthen management to provide a good platform for the traditional music inheritance.

\section{Improve the Music Teaching System}

It is the aim of the development of colleges and universities to do profound knowledge study, cultivate high quality talent and inherit and innovate culture. It is also a kind of sublimation to education that the traditional music can be inherited and protected via the school. Young people is the majority in the aspect of loving music according to the age, thus it will play much more efficiency to take the intangible cultural heritage of music into the college music teaching system. After one thousand years vicissitudes of life, the traditional Chinese music is not only a perfect poem created by generation after generation of musicians \& artists, but also the spirit of people. When history passes music to us, it also passes the politic, economic and culture at the same time which provides a lot of the basis for studying the music and history to us. A song of "House of Flying Daggers" shows the bloody and wisdom of the battle of Chu and Han in 202 BC; A song "Jasmine" not only conveys the love, but also embodies the implication beauty of waterside Jiangnan culture; The "Colorful Plumage Dance" led us to the prosperous world of Tang.
To fully integrate the non-material cultural heritage of music into the music teaching not only can improve the present problem of the "disorders of Chinese and western" in music curriculum ( such as in the education theory, basic theory and training patterns curriculum, colleges and universities mainly adopt western music), but also can achieve the rational regression of the Chinese music culture in music teaching of colleges and universities, which is an important way to transform inferior position of the Chinese music in the music education in collages and universities.

\section{CONCLUSION}

To sum up, the Chinese has the rich traditional music culture in the five thousand - year history, which is an important inheritance in people's oral and non-material culture.

To improve the speed of economic and social development and the impact of the modern music culture, traditional music in China has had the great change, also cause the loss of traditional music culture foundation and extinction. The Chinese traditional music has had great change because of the improvement of the fast speed of economic and social development and the impact of the modern music culture which cause the loss and extinction of some traditional music culture foundation. Thus, it is very important to the inheritance and protection of the nonmaterial culture of music that how to intensify the protection of it, how to preserve the Chinese traditional culture and how to promote the nation spirit.

\section{REFERENCES}

[1] Wei Wang. The first thinking of protection and inheritance on the non-material cultural heritage of music in Jiangsu[J]. Chinese music. 2009(01)

[2] Meiqin Wen. Simple analysis on the necessary of protection and inheritance of the non material culture of music[J]. Music space time. 2013(16)

[3] Yan Sun. The function of regional colleges for the protection and inheritance of non-material cultural heritage $[\mathrm{J}]$. College journal of Yuxi Teachers College. 2007(10)

[4] Chunling Huang, Mengtao Qiao. Thinking of improving the teaching quality about the public elective courses of music in college [J].College journal of Hebei Agricultural University (education edit of agriculture \& forest).2009(02)

[5] Xiaoyu Xiong, Dalin Tang. Para international academic front structure analysis of school in China-- the review about the first master classes of the music (analysis) theory in the whole country [J]. People's music. 2012(10)

[6] Sumin Hao. Cultural field and the "flowers" in ceremony - Discuss the protection of non-material cultural heritage from the view of human beings.[J]. Research on national literature.2005(04)

[7] Sandeno. "Do something" and also "leave some things undone" Discussion about the basic idea and practice method of non-material cultural heritage of music[J]. Chinese music. 2008 (02) 